\title{
Effect of Application Schedule of Microbial and Chemical Insecticides on Insect-Pest Control and Grain Yield of Mungbean (Vigna radiata (L.) Wilczek)
}

\author{
Sanjeet Kumar Singh ${ }^{1}$, Anil Kumar Singh ${ }^{2 *}$, Jay Prakash Singh $^{3}$ and \\ Vijayanand Pathak ${ }^{4}$
}
${ }^{1}$ Department of Entomology, ${ }^{2}$ Department of Agricultural Chemistry \& Soil Science, ${ }^{3}$ Department of Plant Pathology, ${ }^{4}$ Department of Genetics \& Plant Breeding, S. M. M. Town P. G. College, Ballia - 277 001, UP, India

*Corresponding author

\begin{tabular}{|l|}
\hline Ke y w o r d s \\
$\begin{array}{l}\text { Microbial insecticide, } \\
\text { Chemical Insecticide, } \\
\text { White fly, Jassid, Thrips, } \\
\text { Mungbean, Yield }\end{array}$ \\
\hline Article Info \\
\hline $\begin{array}{l}\text { Accepted: } \\
\text { 12 August } 2018 \\
\text { Available Online: } \\
\text { 10 September } 2018\end{array}$ \\
\hline
\end{tabular}

A B S T R A C T
Present investigation revealed that three species of insect-pests viz. white fly (Bemisia tabaci), jassid (Empoasca kerri) and thrips (Caliothrips indicus) were found as major insect-pests of mungbean on the basis of their population build up and severity of infestation. White fly, jassid and thrips attacked the mungbean from seedling to maturity stage. Among the microbial and chemical insecticides combination of seed treatment with Pseudomonas florescens + Beauveria bassiana (spraying) gave better response and was found most effective against white fly followed by seed treatment with Pseudomonas florescens. Similarly in case of jassid, the seed treatment with imidacloprid gave better result followed by combination of seed treatment with Beauveria bassiana + Pseudomonas florescens. In case of thrips, combination of seed treatment with Beauveria bassiana gave best performance with lowest thrips infestation and highest reduction over control, followed by the seed treatment with imidacloprid. All the insecticides found to be effective in increasing the yield over control. The highest yield (6.98) $\mathrm{q} \mathrm{ha}^{-1}$ was recorded in combination of seed treatment with Beauveria bassiana and spray with profenophos followed by combination of seed treatment with Pseudomonas florescens + spray with $B$. bassiana $\left(6.42 \mathrm{q} \mathrm{ha}^{-1}\right)$.

\section{Introduction}

India is the largest producer, importer and consumer of pulses, accounting for $25 \%$ of global production from $35 \%$ area under pulses
(Ahlawat et al., 2016). In India, the area under pulses are 26.28 million ha (2010-11), and the production is 19.78 million tonnes during 2013-14. The productivity of pulses in the country is $789 \mathrm{~kg} \mathrm{ha}^{-1}$ in the year 2012-13 
(GoI, 2015). Countries like India where a large population is vegetarian, pulses are the cheap and best source of protein. Pulses besides being rich in protein (about 25\%) and some of essential amino acids, enrich the soil through symbiotic fixation of atmospheric nitrogen. Pulses are important for sustainable agriculture as they improve physical, chemical and biological properties of soil and function as mini nitrogen factory.

Among the pulses mungbean (Vigna radiata (L.) Wilczek) is one of the important pulse crop in India which also known as green gram. In India, the area under mungbean is $3.19 \mathrm{~m}$ ha with the production of 1.48 million tonnes having an average yield of $463 \mathrm{~kg} \mathrm{ha}^{-1}$ (Ahlawat et. al., 2016). There is number of constraints for low production of mungbean in India, out of those insect-pests play major role in low production. The green gram are attacked by various insect pests such as blister beetle (Mylabris pustulata), gram caterpillar, spotted pod-borer (Maruca testulalis), tobacco caterpillar (Spodoptera litura), galerucid beetle (Madurasia obscurella), aphids (Aphis craccivora), jassids, pod sucking bugs (Anoplocnemis phasiana), thrips (Taeniothrips spp.), stem fly (Melanagromyza phaseoli and white fly. Out of these sucking pests contribute heavily towards losses in yield. The most serious pest problems include the white fly, bean thrips (Megalurothrips distalis), gram pod borer (Helicoverpa armigera) and legume pod borer (Maruca vitrata) (Kooner et al., 2006).

Insecticide application has been one of the effective and quick methods of reducing insect pest population in the field. More often it forms the only solution to outbreaks of insects. However, to minimize the insecticide load in produce and to protect environment from adversities of agrochemicals, the substitution of hazardous conventional insecticides with bio-inoculants is the need of the time. The performance of new group of insecticide in changing insect plantenvironment interaction, with specific knowledge of host plant resistance mechanism must be emphasized to develop an economic strategy against insect pests of mungbean. Therefore, in order to minimize the losses caused by the insect pests in mungbean, present investigation was carried out during the Kharif, 2009 to evaluate the effect of application schedules of eco-friendly insecticides against major insect-pest of mungbean.

\section{Materials and Methods}

\section{Physiography and climatic conditions}

The present study 'Effect of application schedule of microbial and chemical insecticides on insect-pest control and grain yield of mungbean' was carried out during Kharif season of 2009-2010 at the Agricultural Research Farm, Institute of Agricultural Sciences, BHU, Varanasi, UP, India. This research Farm is situated approximately in the center of North Gangetic alluvial plains on the bank of river Ganga. It is located on $25^{\circ} 20^{\prime} \mathrm{N}$ latitude and $83^{\circ} 0^{\prime} \mathrm{E}$ longitude and at an altitude of 75.70 meters above the mean sea level. Being located in the semi-arid zone, its climate is sub-tropical. Annual mean precipitation ranges approximately from $75 \mathrm{~cm}$ to $100 \mathrm{~cm}$, which is mostly confined to Kharif season. During summer the hotter months are May and June, while cold spell starts from last week of December and continue till middle of January.

\section{Layout and experimental details}

The mungbean variety HUM-12 which is commonly cultivated in the area was grown in plots having 10 rows, plot size $4 \times 3$ meter in each plot. The plant spacing between rows and plants were maintained $30 \mathrm{~cm}$ and $10 \mathrm{~cm}$, 
respectively. The crop was grown as per the normal agronomic practices following Factorial Randomized Block Design. There were total 10 treatments including control and these treatments were replicated 3 times each. The details about the insecticides being used are given in Table 1. The seed treatment was prepared by mixing the required quantity of the insecticides formulation in desired quantity of seed along with gum manually. The treated seeds were dried in shade. The spray mixture of each treatment was prepared by mixing the required quantity of the insecticides formulation in clean water to make it equivalent to 600 liters $\mathrm{ha}^{-1}$. The spray mixtures were freshly prepared for each treatment. The spraying was done by ASPEE foot sprayer fitted with cone type nozzle. The sprayer was duly calibrated with water for the application rate of 600 liters spray mixture ha 1. The applications of the treatment started with the start of flowering stage of the crop (40 DAS) and were applied twice at the interval of 15 days during the experimentation. In control, the plain water was sprayed. To avoid the drift of spray fluid to the adjacent plot, insecticides were applied uniformly during early hours of the day when wind velocity was suitable for spraying. The sprayer was thoroughly washed after spraying of each insecticide.

\section{Sampling and observation}

The observations were recorded using rectangular split cage, on the incidence of insect-pests. From each plot five observations were taken. Insect population was counted 1 day before the insecticidal application and $3^{\text {rd }}$ and $7^{\text {th }}$ day after spraying for determining the effect of eco-friendly insecticides and per cent reduction in population. For plot yield all the plants were harvested and the sample yield was added to this yield to get the plot yield for each treatment. The plot yield was then converted to yield hectare ${ }^{-1}$.

\section{Results and Discussion}

\section{Occurrence of insect-pests}

The insect pests recorded infesting mungbean crop is listed in Table 2. The incidence of insect pests recorded in the experimental plots showed that the pests, which appeared on mungbean crop at various plant growth stages, were white fly, jassid and thrips from seedling to maturity stage of the crop. Bihar hairy caterpillar is a sporadic pest and was found during vegetative to maturity stages of crop while gram pod borer was recorded during pod maturity stage of the crop. Five insect pests have been reported on the crop. Several workers have also reported the insect pests of mungbean including those recorded in the present study (Sahoo and Patanaiak, 1994, Singh and Kalra, 1995). It has been noticed in the present study made in Kharif season that the mungbean crop harboured more number of insect pests with higher infestation rate. It might be due to high temperature prevailing during the summer season which has contributed to a decline in pest incidence whereas scattered rain shower and high relative humidity favoured the population buildup of the pest. Yadav et al., (2006) in a forecast models study against thrips, jassid and whitefly attacking mungbean reported that the cumulative effect of environmental factors was more pronounced during the rainy season with marked effect of maximum temperature, whereas minimum temperature and relative humidity exhibited negative response in summer. Rainfall was slightly conducive during summer, but its effect in the rainy season was adverse on thrips population.

\section{Effect of eco-friendly insecticide on the} population of white fly

The application of eco-friendly insecticides in experimental plot revealed variation in per 
cent reduction of insect population Table 3 . The data showed that seed treatment and its combination with foliar spray were found effective to reduce the insect population. Among seed treatments, imidacloprid $\left(\mathrm{T}_{4}\right)$ was found most superior in reducing insect population $(66.96 \%)$ at 3 days after spraying whereas seed treatment with Pseudomonas florescence $\left(\mathrm{T}_{2}\right)$ showed $82.36 \%$ population reduction of whitefly at 7 days after spraying. Among combination of seed treatment and foliar application, imidacloprid (ST) + spraying with profenophos $\left(\mathrm{T}_{9}\right)$ was most effective in reducing white fly population $(63.52 \%)$ at 3 days after spray while seed treatment with Pseudomonas florescens + profenophos $\left(\mathrm{T}_{8}\right)$ reduced maximum per cent of white fly population (55\%) at 7 days after spray. In second application schedule i.e. treatments were given at 55 days after sowing observed that among seed treatments, Beauveria bassiana $\left(\mathrm{T}_{1}\right)$ were found most superior by reducing $68.49 \%$ population of white fly at 3 days after spraying whereas seed treatment with Beauveria bassiana $\left(\mathrm{T}_{1}\right)$ showed $86.16 \%$ population reduction of white fly at 7 days after spraying. In combinations of seed treatment and foliar spray, Pseudomonas florescens (ST) + Beauveria bassiana $\left(\mathrm{T}_{6}\right)$ was observed most effective in reducing population of white fly $(87.22 \%)$ at 3 days after spray whereas Beauveria bassiana $\left(\mathrm{T}_{1}\right)$ reduced $90.18 \%$ population of white fly at 7 days after spray. The overall, pooled data of both the application schedule i.e. spraying at 40 and 55 days after sowing revealed that maximum per cent reduction in population of white fly was observed in seed treatment of Beauveria bassiana (60.87\%) followed by treatment combination of Beauveria bassiana (ST)+ profenophos (SP) which reduced 59.86 per cent population of white fly.

Two sprays with combination of seed treatment with Pseudomonas florescens + spray with Beauveria bassiana proved most effective in controlling the white fly. The performance of seed treatment with Pseudomonas florescens (seed treatment) was next in order of effectiveness, although population of white fly was comparatively higher in plot treated with Beauveria bassiana $(\mathrm{ST})+$ Beauveria bassiana (Sp), imidacloprid, Beauveria bassiana or Pseudomonas florescens alone but when these were used combining with profenophos all these treatments reduced the population significantly. The results of the present study are similar to the finding of Khuroo et al., (2003) which proved that the spraying of imidacloprid reduced the white fly population and gave the highest average yield. Afzal et al., (2002) also observed the spray of imidacloprid as the most effective treatment for control of white fly population.

\section{Effect of eco-friendly insecticide on the population of Jassid}

The data presented in Table 4 showed that seed treatment and its combination with foliar spray were found effective to reduce the insect population. Among seed treatments Beauveria bassiana $\left(\mathrm{T}_{1}\right)$ was found most superior in reducing insect population $96.22 \%$ and $94.07 \%$ at 3 and 7 days after spraying, respectively. Among combination of seed treatment and foliar application, B. bassiana $(\mathrm{ST})+$ spraying with Profenophos $\left(\mathrm{T}_{7}\right)$ was most effective in reducing jassid population $(74.08 \%)$ at 3 days after spray while seed treatment with imidacloprid + profenophos $\left(\mathrm{T}_{9}\right)$ reduced maximum per cent of jassid population (69.58\%) at 7 days after spray. In second application schedule i.e. treatments given at 55 days after sowing showed that among seed treatment, Beauveria bassiana + Pseudomonas florescens $\left(\mathrm{T}_{3}\right)$ was found to be most superior by reducing $86.91 \%$ and $92.46 \%$ population of jassid at 3 and 7 days after spraying, respectively. 
Table.1 Details of treatments applied in the field trial

\begin{tabular}{|c|c|c|}
\hline Sl. No. & Name of the treatments & Rate of application \\
\hline 1 & Beauveria bassiana (ST) $\mathrm{T}_{1}$ & $10 \mathrm{~g} \mathrm{~kg}^{-1}$ \\
\hline 2 & Pseudomonas florescens (ST) $\mathrm{T}_{2}$ & $10 \mathrm{~g} \mathrm{~kg}^{-1}$ \\
\hline 3 & B. bassiana $+P$. florescens $(\mathrm{ST}) \mathrm{T}_{3}$ & $5 \mathrm{~g}+5 \mathrm{~g} \mathrm{~kg}^{-1}$ \\
\hline 4 & Imidacloprid (ST) $\mathrm{T}_{4}$ & $5 \mathrm{~g} \mathrm{~kg}^{-1}$ \\
\hline 5 & B. bassiana $(\mathrm{ST})$ and B. bassiana $(\mathrm{Sp}.) \mathrm{T}_{5}$ & $10 \mathrm{~g} \mathrm{~kg}^{-1}+1200 \mathrm{~g} \mathrm{ha}^{-1}$ \\
\hline 6 & P. florescens $(\mathrm{ST})$ and B. bassiana $(\mathrm{Sp}.) \mathrm{T}_{6}$ & $10 \mathrm{~g} \mathrm{~kg}^{-1}+1200 \mathrm{~g} \mathrm{ha}^{-1}$ \\
\hline 7 & B. bassiana $(\mathrm{ST})$ and Profenophos $(\mathrm{Sp}.) \mathrm{T}_{7}$ & $10 \mathrm{~g} \mathrm{~kg}^{-1}+1200 \mathrm{~g} \mathrm{ha}^{-1}$ \\
\hline 8 & P. florescens (ST) and Profenophos (Sp.) $\mathrm{T}_{8}$ & $10 \mathrm{~g} \mathrm{~kg}^{-1}+1200 \mathrm{~g} \mathrm{ha}^{-1}$ \\
\hline 9 & Imidacloprid (ST) and Profenophos (Sp.) $\mathrm{T}_{9}$ & $5 \mathrm{~g} \mathrm{~kg}^{-1}+1200 \mathrm{~g} \mathrm{ha}^{-1}$ \\
\hline 10 & Control $\mathbf{T}_{10}$ & Water spray \\
\hline
\end{tabular}

ST - Seed treatment, Sp - Spraying.

Table.2 List of major insect-pests of mungbean recorded during experimentation

\begin{tabular}{|c|c|c|c|c|}
\hline S. No. & Insect & Families & Order & Nature of damage \\
\hline \multicolumn{5}{|c|}{ A. Sap-feeder } \\
\hline 1 & Whitefly, Bemisia tabaci (Genn.) & Aleurodidae & Hemiptera & Sucking pests, leaves \\
\hline 2 & Jassid, Empoasca kerri (Pruthi) & Jassidae & Hemiptera & Sucking pests, leaves \\
\hline 3 & Thrips, Caliothrips indicus (Bagnall) & Thripidae & Thysanoptera & Sucking pests, leaves \\
\hline \multicolumn{5}{|c|}{ B. Defoliators } \\
\hline 4 & $\begin{array}{l}\text { Bihar hairy caterpillar, Spilosoma } \\
\text { obliqua (Walker) }\end{array}$ & Arctiidae & Lepidoptera & Defoliator \\
\hline \multicolumn{5}{|c|}{ C. Borers } \\
\hline 5 & $\begin{array}{l}\text { Gram caterpillar, Helicoverpa } \\
\text { armigera }(\text { Hub.) }\end{array}$ & Noctuidae & Lepidoptera & Pod borer \\
\hline
\end{tabular}


Table.3 Effect of application schedule of eco-friendly insecticide against white fly infesting mungbean

\begin{tabular}{|c|c|c|c|c|c|c|c|}
\hline \multirow{3}{*}{ Treatments } & \multicolumn{7}{|c|}{ White fly population cage ${ }^{-1}$} \\
\hline & \multicolumn{3}{|c|}{ After $1^{\text {st }}$ spray } & \multicolumn{3}{|c|}{ After $2^{\text {nd }}$ spray } & \multirow[b]{2}{*}{ Average } \\
\hline & 3 DAS & 7 DAS & Average & 3 DAS & 7 DAS & Average & \\
\hline Beauveria bassiana (ST.) $\mathrm{T}_{1}$ & $42.7(6.62)$ & $46.04(6.86)$ & $44.41(6.74)$ & $68.49(8.34)$ & $86.16(9.34)$ & $77.32(8.85)$ & $60.86(7.87)$ \\
\hline Pseudomonas florescence (ST.) $\mathbf{T}_{2}$ & $28.5(5.43)$ & $82.36(9.13)$ & $55.41(7.51)$ & $63.27(8.02)$ & $83.34(9.18)$ & $73.31(8.62)$ & $64.36(8.08)$ \\
\hline B. bassiana $+P$. florescens $(\mathrm{ST}.) \mathbf{T}_{3}$ & $38.9(6.32)$ & $33.61(5.88)$ & $36.24(6.10)$ & $42.17(6.57)$ & $64.63(8.10)$ & $53.40(7.38)$ & $44.82(6.77)$ \\
\hline Imidacloprid (ST.) $\mathbf{T}_{4}$ & $66.9(8.24)$ & $42.45(6.59)$ & $54.70(7.46)$ & $59.99(7.81)$ & $22.23(4.82)$ & $41.11(6.49)$ & $47.90(6.99)$ \\
\hline B. bassiana (ST.) and B. bassiana (Sp.) $\mathbf{T}_{5}$ & $58.1(7.69)$ & $33.82(5.90)$ & $45.96(6.85)$ & $33.47(5.87)$ & $90.15(9.55)$ & $61.81(7.93)$ & $53.9(7.41)$ \\
\hline P. fluorescence $(\mathrm{ST})$ and B. bassiana $(\mathrm{Sp}.) \mathbf{T}_{6}$ & $46.9(6.92)$ & $52.83(7.34)$ & $49.89(7.13)$ & $87.22(9.39)$ & $74.36(8.68)$ & $80.79(9.04)$ & $65.34(8.14)$ \\
\hline B. bassiana (ST.) and profenophos (Sp.) $\mathrm{T}_{7}$ & $50.9(7.21)$ & $19.88(4.57)$ & $35.40(6.03)$ & $84.69(9.26)$ & $84.02(9.22)$ & $84.35(9.24)$ & $59.87(7.80)$ \\
\hline P. florescens (ST.) and profenophos (Sp) $\mathbf{T}_{8}$ & $28.7(5.46)$ & $55.10(7.49)$ & $41.93(6.55)$ & $77.13(8.84)$ & $66.67(8.23)$ & $71.90(8.54)$ & $56.91(7.61)$ \\
\hline Imidacloprid (ST.) and profenophos (Sp.) $\mathbf{T}_{9}$ & $63.5(8.03)$ & $45.21(6.80)$ & $54.36(7.44)$ & $23.46(4.95)$ & $64.48(8.09)$ & $43.97(6.71)$ & $49.16(7.08)$ \\
\hline Control (Water spray) $\mathbf{T}_{10}$ & $70.20(9.37)$ & $85.26(10.23)$ & 77.73(9.81) & $89.36(10.45)$ & $92.45(10.61)$ & $90.90(10.53)$ & $84.31(10.18)$ \\
\hline
\end{tabular}

Note: Figures in parentheses are transformed as $\sqrt{ } \mathrm{x}+1$; DAS $=$ Days after spraying, $\mathrm{ST}=$ Seed treatment, $\mathrm{Sp}=\mathrm{spraying}$

1. Difference between treatment C.D. $(\mathrm{P}=0.05)=2.78$

2. Difference between spray C.D. $(\mathrm{P}=0.05)=1.31$

3. Difference between days after application C.D. $(\mathrm{P}=0.05)=1.32$

4. Interaction between spray $x$ days C.D. $(\mathrm{P}=0.05)=1.86$

5. Interaction between spray $x$ treatment C.D. $(P=0.05)=3.94$

6. Interaction between days $x$ treatment C.D. $(\mathrm{P}=0.05)=3.93$

7. Interaction between spray $x$ days $x$ treatment C.D. $(\mathrm{P}=0.05)=5.5$ 
Table.4 Effect of application schedule of eco-friendly insecticide against jassid infesting mungbean

\begin{tabular}{|c|c|c|c|c|c|c|c|}
\hline \multirow{3}{*}{ Treatment } & \multicolumn{7}{|c|}{ Jassid population cage $^{-1}$} \\
\hline & \multicolumn{3}{|c|}{ After $1^{\text {st }}$ spray } & \multicolumn{3}{|c|}{ After $2^{\text {nd }}$ spray } & \multirow[t]{2}{*}{ Average } \\
\hline & 3 DAS & 7 DAS & Average & 3 DAS & 7 DAS & Average & \\
\hline Beauveria bassiana (ST.) $\mathbf{T}_{1}$ & $96.22(9.86)$ & $94.0(9.75)$ & $95.15(9.81)$ & $51.04(7.21)$ & $92.37(9.66)$ & $71.70(8.53)$ & $83.425(9.19)$ \\
\hline Pseudomonas florescence (ST.) $\mathbf{T}_{2}$ & $86.66(9.36)$ & $28.4(5.43)$ & $57.55(7.65)$ & $84.78(9.26)$ & $90.07(9.54)$ & $87.42(9.40)$ & $72.485(8.57)$ \\
\hline B. bassiana $+P$. florescence $(\mathrm{ST}.) \mathrm{T}_{3}$ & $92.50(9.67)$ & $64.4(8.09)$ & $78.47(8.91)$ & $86.91(9.38)$ & $92.46(9.67)$ & $89.69(9.52)$ & $84.08(9.22)$ \\
\hline Imidacloprid (ST.) $\mathbf{T}_{4}$ & $84.85(9.27)$ & $79.4(8.97)$ & $82.17(9.12)$ & $85.89(9.32)$ & $88.10(9.44)$ & $86.99(9.38)$ & $84.58(9.25)$ \\
\hline B. bassiana (ST.) and B. bassiana $(\mathrm{Sp.}) \mathrm{T}_{5}$ & $50.41(7.17)$ & $31.1(5.67)$ & $40.76(6.46)$ & $55.00(7.48)$ & $90.33(9.56)$ & $72.67(8.58)$ & $56.715(7.60)$ \\
\hline P. fluorescence $(\mathrm{ST})$ and $B$. bassiana $(\mathrm{Sp}.) \mathrm{T}_{6}$ & $30.63(5.62)$ & $50.7(7.20)$ & $40.71(6.46)$ & 92.74(9.68) & 86.83(9.37) & $89.79(9.53)$ & $65.25(8.14)$ \\
\hline B. bassiana (ST.) and profenophos (Sp.) $\mathrm{T}_{7}$ & $74.08(8.66)$ & $20.3(4.62)$ & $47.22(6.94)$ & $91.61(9.62)$ & $68.37(8.33)$ & $79.99(9.00)$ & $63.605(8.04)$ \\
\hline P. florescence (ST.) and profenophos (Sp.) $\mathrm{T}_{8}$ & $66.94(8.24)$ & $17.8(4.34)$ & $42.40(6.59)$ & $95.85(9.84)$ & $92.09(9.65)$ & 93.97(9.75) & $68.185(8.32)$ \\
\hline Imidacloprid (ST.) and profenophos (Sp.) $\mathbf{T}_{9}$ & $61.52(7.91)$ & $69.6(8.40)$ & $65.58(8.16)$ & $60.00(7.81)$ & $57.78(7.67)$ & $58.89(7.74)$ & $62.235(7.95)$ \\
\hline Control (Water spray) $\mathbf{T}_{10}$ & $97.37(10.86)$ & $95.18(10.75)$ & $96.27(10.81)$ & $96.24(10.81)$ & $93.38(10.66)$ & $94.81(10.73)$ & 95.54(10.77) \\
\hline
\end{tabular}

Note: Figures in parentheses are transformed as $\sqrt{ } \mathrm{x}+1, \mathrm{DAS}=$ Days after spraying, $\mathrm{ST}=$ Seed treatment, $\mathrm{Sp}=\mathrm{spraying}$

1. Difference between treatment C.D. $(\mathrm{P}=0.05)=5.62$

2. Difference between spray C.D. $(\mathrm{P}=0.05)=2.65$

3. Difference between days after application C.D. $(\mathrm{P}=0.05)=2.64$

4. Interaction between spray $x$ days C.D. $(P=0.05)=3.75$

5. Interaction between spray $x$ treatment C.D. $(\mathrm{P}=0.05)=7.94$

6. Interaction between days $x$ treatment C.D. $(\mathrm{P}=0.05)=7.93$

7. Interaction between spray $x$ days $x$ treatment C.D. $(\mathrm{P}=0.05)=11.23$ 
Table.5 Effect of application schedule of eco-friendly insecticide on the population of thrips infesting mungbean

\begin{tabular}{|c|c|c|c|c|c|c|c|}
\hline \multirow{3}{*}{ Treatments } & \multicolumn{7}{|c|}{ Thrips population cage $^{-1}$} \\
\hline & \multicolumn{3}{|c|}{ After $1^{\text {st }}$ spray } & \multicolumn{3}{|c|}{ After $2^{\text {nd }}$ spray } & \multirow[t]{2}{*}{ Average } \\
\hline & 3 DAS & 7 DAS & Average & 3 DAS & 7 DAS & Average & \\
\hline Beauveria bassiana (ST.) $\mathbf{T}_{1}$ & $70.6(8.47)$ & $72.01(8.54)$ & $71.34(8.51)$ & $17.94(4.35)$ & $26.10(5.21)$ & $22.02(4.80)$ & $46.69(6.91)$ \\
\hline Pseudomonas florescence (ST.) $\mathrm{T}_{2}$ & $36.8(6.15)$ & $46.62(6.90)$ & $41.74(6.54)$ & $20.75(4.66)$ & $23.39(4.94)$ & $22.07(4.80)$ & $31.91(5.74)$ \\
\hline B. bassiana + P. florescence $(\mathrm{ST}.) \mathrm{T}_{3}$ & $70.7(8.47)$ & $28.22(5.41)$ & $49.48(7.11)$ & $16.17(4.14)$ & $12.86(3.72)$ & $14.52(3.94)$ & $31.99(5.74)$ \\
\hline Imidacloprid (ST.) $\mathbf{T}_{4}$ & $54.2(7.44)$ & $47.29(6.95)$ & $50.79(7.20)$ & $39.76(6.38)$ & $24.15(5.02)$ & $31.96(5.74)$ & $41.37(6.51)$ \\
\hline B. bassiana (ST.) and B. bassiana (Sp.) $\mathbf{T}_{5}$ & $47.8(6.99)$ & $45.67(6.83)$ & $46.75(6.91)$ & $28.72(5.45)$ & $28.53(5.43)$ & $28.63(5.44)$ & $37.68(6.22)$ \\
\hline P. florescence (ST) and B. bassiana (Sp.) $\mathbf{T}_{6}$ & $26.1(5.21)$ & $57.05(7.62)$ & $41.60(6.53)$ & $23.67(4.97)$ & $24.01(5.00)$ & 23.84(4.98) & $32.73(5.81)$ \\
\hline B. bassiana (ST.) and profenophos (Sp.) $\mathbf{T}_{7}$ & $55.1(7.49)$ & $46.01(6.86)$ & $50.59(7.18)$ & $20.78(4.67)$ & $32.92(5.82)$ & $26.85(5.28)$ & $38.72(6.30)$ \\
\hline P. florescence (ST.) and profenophos (Sp.) $\mathbf{T}_{8}$ & $50.0(7.15)$ & $40.35(6.43)$ & $45.21(6.80)$ & $23.50(4.95)$ & $22.17(4.81)$ & $22.83(4.88)$ & $34.02(5.92)$ \\
\hline Imidacloprid (ST.) and profenophos (Sp.) $\mathbf{T}_{9}$ & $29.9(5.56)$ & $67.86(8.30)$ & $48.89(7.06)$ & $14.45(3.93)$ & $26.11(5.21)$ & $20.28(4.61)$ & $34.58(5.97)$ \\
\hline Control (Water spray) $\mathbf{T}_{10}$ & $72.56(9.51)$ & 75.64(9.69) & $74.10(9.60)$ & $50.32(8.09)$ & $52.26(8.22)$ & $51.29(8.16)$ & $62.67(8.91)$ \\
\hline
\end{tabular}

Note: Figures in parentheses are transformed as $\sqrt{ } \mathrm{x}+1$; DAS $=$ Days after spraying, $\mathrm{ST}=$ Seed treatment, $\mathrm{Sp}=\mathrm{spraying}$

1. Difference between treatment C.D. $(\mathrm{P}=0.05)=5.27$

2. Difference between spray C.D. $(\mathrm{P}=0.05)=2.49$

3. Difference between days after application C.D. $(\mathrm{P}=0.05)=2.48$

4. Interaction between spray $x$ days C.D. $(P=0.05)=3.52$

5. Interaction between spray $x$ treatment C.D. $(\mathrm{P}=0.05)=7.45$

6. Interaction between days $x$ treatment C.D. $(\mathrm{P}=0.05)=7.44$

7. Interaction between spray $x$ days $x$ treatment C.D. $(P=0.05)=10.54$ 


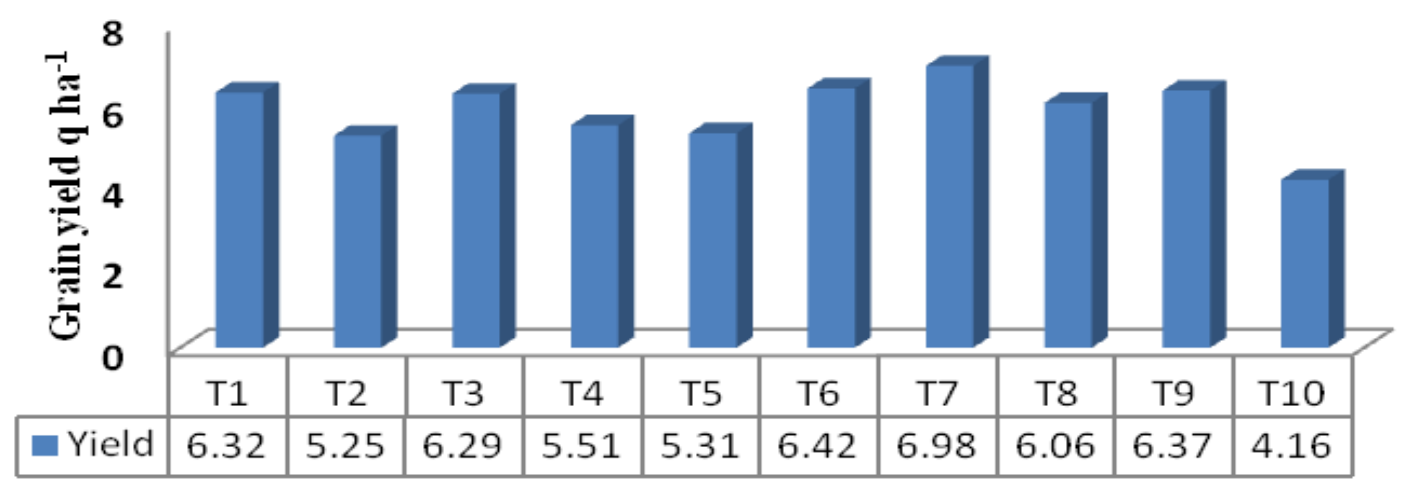

Fig. 1 Effect of insectides on the grain yield of mungbean

In combinations of seed treatment and foliar spray, Pseudomonas florescens (ST) + profenophos $\left(\mathrm{T}_{8}\right)$ was observed most effective in reducing population of jassid $(95.85 \%)$ at 3 days and $(92.09 \%)$ at 6 days after spray. Pooled data of both the application schedule revealed that maximum percent reduction in population of jassid was observed in seed treatment of imidacloprid $(84.5 \%)$ followed by treatment combination of Beauveria bassiana (ST) + Pseudomonas florescence (ST) which reduced $84.08 \%$ population of jassid.

Application of two sprays with combination of seed treatment with imidacloprid (ST) proved most effective in reducing the population of jassid. The performance of seed treatment with Beauveria bassiana + Pseudomonas florescens was next in order for reducing the population, although population of jassid was comparatively higher in plot treated with imidacloprid $(\mathrm{ST})+$ profenophos (Sp). Our results are similar to the findings of Satpute et al., (2001) who have reported the efficacy of the seed dresser insecticides, imidacloprid which reduced the jassid population significantly.
Effect of eco-friendly insecticide on the population of thrips

Overall performance of all the microbial and chemical insecticidal treatment showed that all the insecticides (except seed treatment with Pseudomonas florescens and seed treatment with Beauveria bassiana + Pseudomonas florescens) were effective in controlling the thrips population after 3 and 7 days after spraying which gave higher crop yield in comparison to control plot (Table 5). Seed treatment with Beauveria bassiana proved most effective in controlling the thrips. Also the performance of treatment combination of showed next in order to effectiveness, although population of thrips was comparatively higher in plot treated with imidacloprid alone but when these insecticides are used in combination with profenophos, these showed better effect in aspect to reducing the thrips population. Afzal et al., (2002) also observed that the spray of imidacloprid was found to be most effective for control of thrips population. Sreekanth et al., (2003) also reported the imidacloprid schedules tested significantly reduced the Thrips palmi population in the urd bean crop field. Nayak et al., (2004) also evaluated the 
efficacy of different combinations of insecticides amongst which imidacloprid as seed treatment against thrips was most effective.

\section{Grain yield}

The grain yield data depicted in figure 1 indicated that the microbial and chemical insecticides were effective in increasing the yield over control. The combination of microbial and chemical insecticides found better in efficacy to check the attack of insect pests and as a result of Beauveria bassiana + profenophos registered highest yield i.e. 6.98 $\mathrm{q}$ ha $^{-1}$ followed by combination of seed treatment with Pseudomonas florescens + spray with Beauveria bassiana, imidacloprid $(\mathrm{ST})+$ profenophos $(\mathrm{Sp})$ which reported 6.42 $\mathrm{q} \mathrm{ha}^{-1}$ and $6.37 \mathrm{q} \mathrm{ha}^{-1}$ yield, respectively. In agreement with these results Ganapathy and Karuppi (2004) reported the efficacy of new insecticide imidacloprid used as seed treatment which gave the better yield. Shah et al., (2007) studied the efficacy of imidacloprid, acetamiprid, buprofezin and thiomethoxam on jassids, whiteflies and thrips infesting mungbean and reported that imidacloprid gave the highest number of seeds per pod, 1000-seed weight and seed yield.

On the basis of the findings, it is concluded that two sprays of microbial and chemical insecticides i.e. combination of seed treatment with Pseudomonas florescens + Beauveria bassiana ( $\mathrm{Sp}$ ) gave most effective control of white fly and seed treatment with imidacloprid, gave most effective control of jassid. Two sprays of microbial and chemical insecticides i.e. combination of seed treatment with Beauveria bassiana gave best performance with lowest thrips infestation and highest reduction over control. Further the combination of seed treatment with Beauveria bassiana + spray with profenophos gave best performance and highest yield followed by combination of Pseudomonas florescens (ST) + Beauveria bassiana (Sp), imidacloprid (ST) + profenophos (Sp), Beauveria bassiana (ST), seed treatment with Beauveria bassiana + Pseudomonas florescens, Pseudomonas florescens (ST) + profenophos (Sp), imidacloprid (ST) and Pseudomonas. florescens, respectively.

\section{References}

Afzal, M., Ahmad, T. and Bashir, M. H. (2002) Relative toxicity of different insecticides against whitefly, (Bemisia tabaci Genn.) and black thrips, Caliothrips indicus on NM-92 mung bean, (Vigna radiata L.). Pakistan Journal of Agricultural Sciences 39 (3), 224-225.

Ahlawat, I. P. S., Sharma, P. and Singh, U. (2016) Production, demand and import of pulses in India, Indian Journal of Agronomy 61 (4th IAC Special issue), S33-S41.

Asthana, A. N. and Chaturvedi, S. K. (1999) A little impetus needed. The Hindu Survey of Indian Agriculture (annual) pp. 61-65.

Ganapathy, T. and Karuppiah, R. (2004) Evaluation of new insecticides for the management of whitefly (Bemisia tabaci Genn.), mungbean yellow mosaic virus (MYMV) and urdbean leaf crinkle virus (ULCV) diseases in mungbean (Vigna radiata (L.) Wilczek). Indian Journal of Plant Protection 32, 35-38.

GoI. (2015) Agricultural Statistics at a Glance 2014, pp. 1-452. Directorate of Economics and Statistics, Ministry of Agriculture, Government of India, New Delhi.

Khuroo, M. S., Khare, C. P., Tiwari, P. K. and Shrivastava, S. K. (2003) Possibilities of imidacloprid incorporation for the management of white fly Bemisia 
tabaci Gann. on chilli. Environment and Ecology 21(1), 214-217.

Kooner, B. S., Cheema, H. K., and Kaur, R. (2006) Insect pest and their management. In: Advances in mungbean and urdbean (Eds. M. Ali and Shiv Kumar), Indian Institute of Pulses Research, Kanpur, pp 335-401.

Nayak, S. K., Ujagir, R. and Chhibber, R. C. (2004) Control of thrips and white fly infesting black gram (Vigna mungo L.) by newer groups of insecticides. Environmen and Ecology 22(3), 538542.

Sahoo, B. K. and Patanaik, N. C. (1994) Insect pests in black gram and green gram in the south coastal region in Orissa with notes on their seasonal activity. Orissa Journal of Agriculture Research 7 (Suppl.), 74-76.

Satpute N. K., Katoke, S. R., Nimalkar, S. A. Sarnaik, D. N. and Satpute, U. S. (2001) Efficacy of imidacloprid and thiamethoxam, seed treatment against cotton jassid Amarasca devatans Distant. Journal of Applied Zoological Research, 12, 88-90.

Shah, M. J., Amir Ahmad, A., Hussain, M., Yousaf, M. M. and Ahmad, B. (2007)
Efficiency of different insecticides against sucking insect-pest complex and effect on the growth and yield of mungbean (Vigna radiata L.). Pakistan Entomologist 29 (2), 83-85.

Singh, R. and Kalra, V. K. (1995) Studies on the insect pest complex associated with summer and kharif mungbean and urd bean (Vigna mungo) in Haryana. Journal of Insect Sciences 8 (2), 181184.

Sreekanth, M., Sriramulu, M., Rao, R. D.V. J. P., Babu, B. S. and Babu, T. R. (2003) Relative efficacy and economics of different imidacloprid schedules against Thrips palmi (Karny), the vector of peanut bud necrosis virus on mungbean (Vigna radiata L. Wilczek). Indian Journal of Plant Protection 31(1), 4347.

Yadav, P. (2006) Forecast models against thrips (Caliothrips indicus) jassid (Empoasca kerri) and whitefly (Bemisia tabaci) attacking mung bean crops Experiments were conducted during summer and rainy seasons of 2003 and 2004 in Kanpur and Etawah, Uttar Pradesh, India.

\section{How to cite this article:}

Sanjeet Kumar Singh, Anil Kumar Singh, Jay Prakash Singh and Vijayanand Pathak. 2018. Effect of Application Schedule of Microbial and Chemical Insecticides on Insect-Pest Control and Grain Yield of Mungbean (Vigna radiata (L.) Wilczek). Int.J.Curr.Microbiol.App.Sci. 7(09): 1717-1727. doi: https://doi.org/10.20546/ijcmas.2018.709.208 